\title{
Óriásnyálkövek: Diagnózis és kezelés
}

\author{
Tordai Bálint dr. - Stáczer Nóra dr. - Vajta László dr. - Szalma József dr.
}

Pécsi Tudományegyetem, Klinikai Központ, Arc-, Állcsont- és Szájsebészeti Tanszék, Pécs

A szerző́k cikküket a Pécsi Tudományegyetem alapitásának 650. évfordulója tiszteletére közlik.

\begin{abstract}
A nyálkövesség az egyik leggyakoribb meszesedés a fej-nyaki régióban. Tünetekkel járó gyakorisága 0,45\% körüli a populációban, míg a tünetmentes esetek gyakorisága az 1\%-ot is meghaladhatja. A maxillofacialis terület nagyobb kiterjedéseit ábrázoló képalkotó eljárások (például: panorámaröntgen, komputertomográfia) a kövesség diagnosztizálását hatékonyan segítik. A nyálkövek mérete általában $1 \mathrm{~cm}$ alatti, míg $15 \mathrm{~mm}$ legnagyobb átmérő felett óriáskövekról beszélhetünk, amelyek leggyakoribb előfordulási helye a submandibularis mirigy vagy annak kivezető csöve. A szerző́k célja volt két óriásnyálköves eset bemutatása (27 és $34 \mathrm{~mm}$ ), ahol az egyik esetben a kő fejlődésének hét évvel korábbi szakaszát is sikerül prezentálniuk. További céljuk volt betekintést nyújtani a nyálkövesség diagnosztikájába és hatékony terápiájába, tárgyalva az esetleges differenciáldiagnosztikai eshetőségeket. Orv. Hetil., 2016, 157(49), 1967-1972.
\end{abstract}

Kulcsszavak: nyálkő, meszesedés, Wharton-vezeték, submandibularis mirigy

\section{Giant sialolithiasis: Diagnosis and management}

\section{Case reports}

Sialolithiasis is one of the most frequent form of calcifications in the maxillofacial area. $0.45 \%$ of the population is affected by symptoms caused by salivary calculi, though the estimated frequency including asymptomatic form may exceed $1 \%$ in adult population. Radiographs presenting a large portion of the maxillofacial region (panoramic radiography, computed tomography) could detect salivary calculi with high accuracy. The size of the sialoliths is usually less than $10 \mathrm{~mm}$ in diameter. Salivary calculi larger than $15 \mathrm{~mm}$ (considering the largest diameter) are classified as giant sialoliths and most of them are located in the submandibular gland or in its duct. Two unusually large submandibular salivary calculi cases are represented (diameters of 27 and $34 \mathrm{~mm}$ ), whereas in one of the cases development and dimensional changes of the calculus are described via a seven years period. This case report represents diagnostic and therapeutic consequences in giant sialolithiasis and demonstrates possible differential diagnostic difficulties.

Keywords: salivary stone, sialolithiasis, giant sialolith, Wharton's duct, submandibular gland

Tordai, B., Stáczer, N., Vajta, L., Szalma, J. [Giant sialolithiasis: Diagnosis and management. Case reports]. Orv. Hetil., 2016, 157(49), 1967-1972.

(Beérkezett: 2016. szeptember 16.; elfogadva: 2016. október 10.)

\section{Rövidítések}

$\mathrm{CBCT}$ = cone beam computed tomography; C3-C4 = cervicalis 3. és 4. csigolya

A nyálkövességet (sialolithiasist) tekinthetjük a nyálmirigy-diszfunkció egyik legfóbb okának. A tünetet produkáló nyálkövesség előfordulása $0,45 \%$ [1]. A nyálkövek 72-94,3\%-a a submandibularis mirigyben vagy a mirigy kivezető csövében fordul elő [2-4] és 94\%-uk röntgenárnyékot ad [3, 4]. Submandibularis nyálkő legnagyobb arányban a Wharton-vezeték distalis szakaszában fordul elő [4].

A nyálkőképződés patogenezise mai napig nem teljesen ismert. Egy kiindulási mag (nidus) szükséges a nyálkő inorganikus összetevőinek lerakódásához, amelyek általában kalcium-foszfát sók. Lelökődő hámsejtek, mikrokövek, tápláléktörmelék, mikroorganizmusok, nyák- 
dugó vagy idegen test (például: halszálka, szőrszál) is funkcionálhat mineralizációs magként [2, 5-7]. A legtöbbet vizsgált és hisztológiailag is alátámasztott elmélet a gyulladásos környezetben előforduló mikrokőképződés. A nyálmirigy gyulladása szöveti ödéma, illetve hegképződés által a kivezető csőrendszer részleges elzáródását okozhatja, amely a kalciumban gazdag szekrétum pangásához vezet. A kalcium kicsapódhat a degradálódó sejtmembránok exponált foszfolipidmolekuláin. A precipitatum nidusként funkcionálhat, és további appozícióval mikrokő (sialomicrolith), végül klinikailag is detektálható nyálkő (sialolith) képződik [1]. Úgy tűnik, a szekrétum pangásának, illetve a csökkent nyáltermelésnek döntő szerepe van a nyálkőképződésben, de számos egyéb etiológiai tényezőnek - fizikai behatás, kivezetőcső morfoanatómiai változatai (szűkület vagy kiöblösödés), nyálösszetétel (túltelítettség vagy precipitációt gátló inhibitor összetevőinek hiánya), bakteriális infekció - is szerepe lehet [5].

A nyálkövek általában a 10 mm-nél kisebb mérettartományba sorolhatók [2-4]. A 15 mm-nél nagyobb átmérőjü nyálköveket óriásnyálkőnek nevezhetjük, amelyek többsége $(94,3 \%)$ a submandibularis nyálmirigyben vagy kivezetőcsövében található [6]. Óriásnyálkő azokban az esetekben alakulhat ki, ha a nyálkövet tartalmazó kivezetőcső-szakasz képes a kő növekedésével párhuzamosan tágulni, ezáltal közel normális exkréciót biztosítani.
A megtartott exkréció miatt a nyálkő növekedése akár hosszú távon is tünetmentes lehet [8].

A nyálkövességet általában az élet 3-6. évtizedeiben diagnosztizálják $[3,4]$. Submandibularis nyálkő átlagosan a 40,5-48. életév között kerül felfedezésre $[1,3]$. Legfóbb panasz a nyálmirigy étkezéskor vagy spontán jelentkező fájdalmas duzzanata, amelynek első megjelenése akár hónapokkal vagy évekkel megelőzheti a diagnózis felállítását, illetve a terápia megkezdését $[3,4]$.

Sialolithiasis esetén az alkalmazott terápia célja elsősorban a fiziológiás nyálszekréció és nyálexkréció helyreállítása, amely az obstrukciót jelentő kő eltávolításával valósítható meg. Napjainkban a minimálisan invazív eltávolítási technikákat részesítjük előnyben, amelyek alapeszköze a szialoendoszkóp. Állandó vizuális kontroll mellett - esettől és technikától függően - több endoszkópos célmû́szer (kosár, fogó) is bevethető, illetve intraductalis kőzúzás is megvalósítható $[9,10]$. Bár az endoszkópos nyálkő-eltávolítás sikeressége magas (76-91\%) [10], óriásnyálkövek eltávolítására ritkán alkalmazott módszer. Számos közleményben óriásnyálkövek eltávolítására továbbra is az intraoralis sebészi feltárásban végzett eltávolítást tekintik az elsődlegesen választandó terápiának [11-13].

A továbbiakban két, óriásnyálkővel diagnosztizált esetünket mutatjuk be, kitérve a diagnózis felállításának menetére, illetve az alkalmazott terápiára.
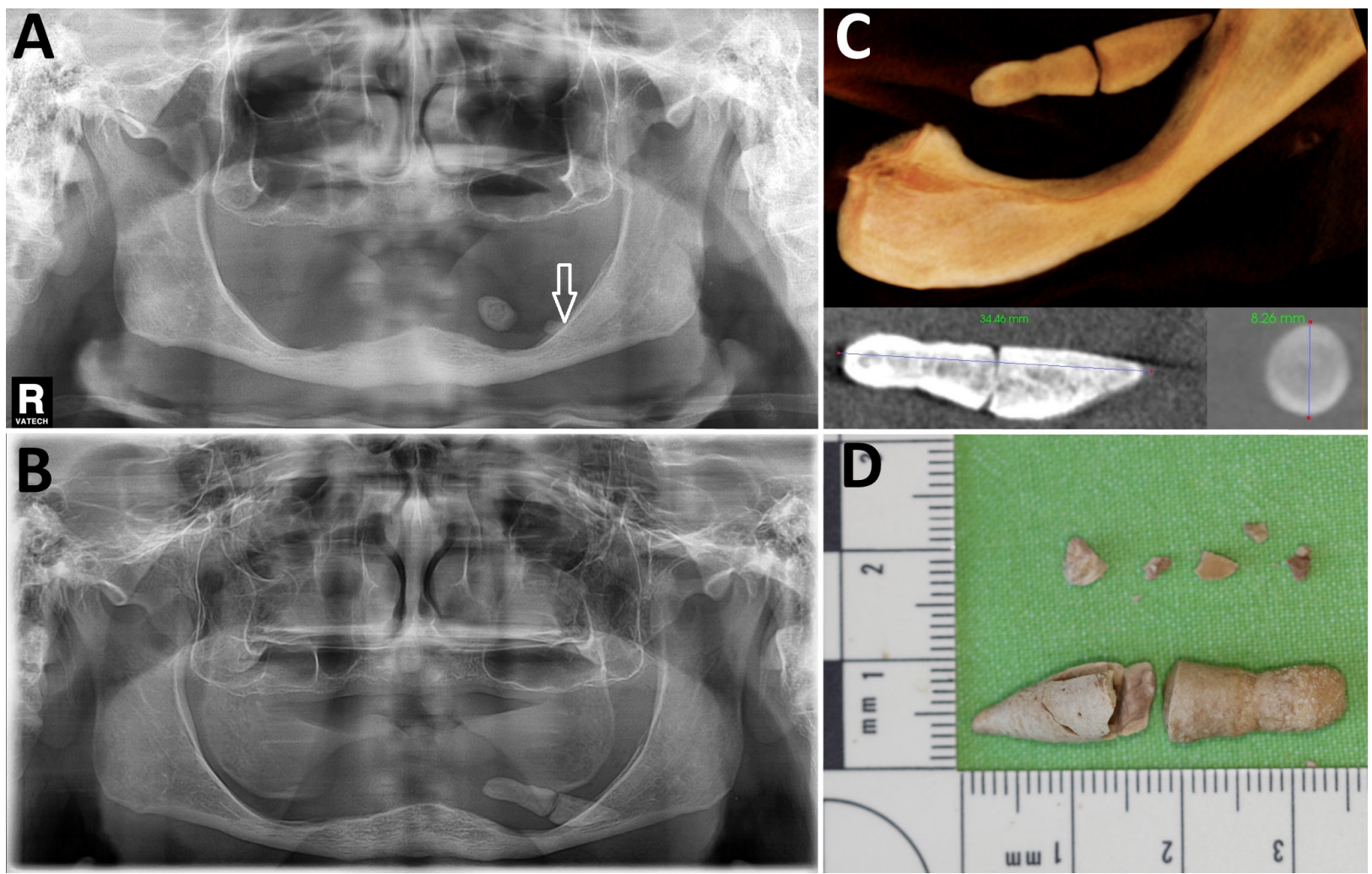

1. ábra $\quad$ A) 2009-ben készült panoráma-röntgenfelvétel. A nyálkő distalis része a fogatlan processus alveolarisra vetül, ezáltal visszamaradt foggyökér röntgenképét imitálja (fehér nyíl). B) 2016-ban készült panorámafelvétel; a nyálkő mérete jelentősen növekedett. C) CBCT-felvételen osztott radiodenz képlet. D) Az eltávolított nyálkő $34 \mathrm{~mm}$ hosszú és 3,8 g, a distalis rész az eltávolítás során morzsolódott 


\section{Esetismertetések}

\section{Elsö eset}

A 67 éves férfi beteg családorvosi beutalóval jelentkezett klinikánkon bal submandibularis trigonum, illetve szájfenék területére lokalizált fájdalmas duzzanattal. Anamnézisünk 2-es típusú cukorbetegséget, illetve ischaemiás szívbetegséget tárt fel. Szisztémás betegségei miatt az alábbi állandó gyógyszeres terápiában részesült: szulfonilurea típusú antidiabetikum (gliclazid), trimetazidin és acetilszalicilsav. 2005-ben epekőképződést diagnosztizáltak, majd cholecystectomiát végeztek nála.

Extraoralis vizsgálatunk során a bal submandibularis régió diffúz, kemény tapintatú, hozzávetőlegesen diónyi méretü, nyomásra érzékeny duzzanatát állapítottuk meg, amelyet ép bőr borított. A páciens elmondása szerint az érintett területen spontán is jelentkező, tompa fájdalom érződött, amely étkezéskor fokozódott. A duzzanat és a fájdalom intermittáló jellegü, megjelenésük esetén a fájdalom intenzitása is változó volt, és általában a terület masszírozásával a terime mérete, illetve a fájdalom erőssége csökkent. Az első tünetek hét-nyolc évvel vizsgálatunkat megelőzően jelentkeztek. Az intraoralis vizsgálat során teljes fogatlanságot állapítottunk meg. Gyulladásos reakciót, illetve tapintásra fájdalmas duzzanatot a szájfenék bal oldalán figyeltünk meg. Bimanuális vizsgálatunk során egy kemény konzisztenciájú, ovális alakú képletet tapintottunk a bal oldali Wharton-vezeték lefutásának megfelelően, elsősorban a szájfenék középső régiójában, a kisörlő fogak helyének vonalában. A bal submandibularis mirigy masszírozásával sürü, gennyes szekrétum távozott a bal caruncula sublingualisból. A kontroll, panaszmentes oldaltól eltérően, itt fiziológiás, víztiszta nyálat nem tudtunk préselni.

Panoráma-röntgenfelvételt és CBCT- (cone beam computed tomography) felvételt készítettünk, amelyek két, egymással kontaktusban lévő, de feltehetően különálló, radiodenz képletet ábrázoltak (1. ábra). A teljes röntgenárnyékot adó struktúra $34,0 \mathrm{~mm} \times 8,2 \mathrm{~mm}$ méretünek bizonyult a CBCT-felvétel alapján. A páciens rendelkezésünkre bocsájtott egy korábbi, 2009-ben készült panoráma-röntgenfelvételt, amely két, egymástól 8 mm távolságra lévő, teljesen szeparált radiodenz struktúrát mutatott, $11,5 \mathrm{~mm} \times 8,5 \mathrm{~mm}$, illetve $10 \mathrm{~mm} \times 4,5$ $\mathrm{mm}$ méretekkel. A páciens elmondása szerint nyálkőképződést vizsgálatunkig nem állapítottak meg, és ennek megfelelően semmilyen gyógyszeres vagy sebészi terápiában nem részesült. Feltételezhetően a 2009-ben készült panorámafelvétel más fogorvosi indikációval készült és az érintett időszakban a páciens tünet- és panaszmentes volt. A vizsgálatunkat megelőző hét-nyolc éves időszakban, a panaszok megjelenésekor (orvosi javaslat nélkül) a páciens nem szteroid gyulladáscsökkentő gyógyszereket használt.

Klinikai és radiológiai vizsgálatunk alapján diagnózisként krónikus obstruktív nyálmiriggyulladást és nyálkövességet állapítottunk meg. Első vizsgálatunk során antibiotikum (sulfamethoxazol/trimethroprim $-2 \times 800$ $\mathrm{mg} / 160 \mathrm{mg}$ naponta, per os), simaizom-spasmolyticum (drotaverin $3 \times 80 \mathrm{mg}$ naponta) és C-vitamin $(2 \times 500$ mg naponta, mint szialogóg) alkalmazását rendeltük, továbbá fokozott napi folyadékbevitelt (>3 liter) és az érintett submandibularis mirigy rendszeres masszírozását javasoltuk. A gyógyszeres terápia negyedik napján intraoralis sebészi feltárásban a nyálköveket eltávolítottuk. Lokális, terminális infiltrációs érzéstelenítést követően ( $2 \mathrm{ml}$; artikain-hidroklorid és 1:100 000 adrenalinhidroklorid) a nyálkő középső harmadát borító nyálkahártyán, illetve a Wharton-vezetéken a kivezetőcső lefutásának megfelelően, rövid metszést ejtettünk. Tompa preparálással láthatóvá tettük a két nyálkődarab összefekvő felszíneit. A mesialis darabot a trigonum submandibulare, illetve trigonum submentale területére gyakorolt craniolateralis irányú nyomással távolítottuk el. A distalis darab frakturált, környezetének masszázsával nem volt kimozdítható, ezért metszésünket distalis irányba meghosszabbítottuk és a nyálkő-fragmentumokat csipesszel kiemeltük (1. D) ábra). A törmelék tökéletes eltávolítása érdekében a Wharton-vezetéket metszésünkön keresztül 22 G szárnyas tű és fecskendő segítségével (B. Braun Melsungen AG, Melsungen, Németország), povidon-jód oldattal (Betadine) mostuk át. A nyálkahártyasebet primeren, egyszerü csomós öltésekkel, nem felszívódó varratokkal zártuk (2. ábra). A Whar-

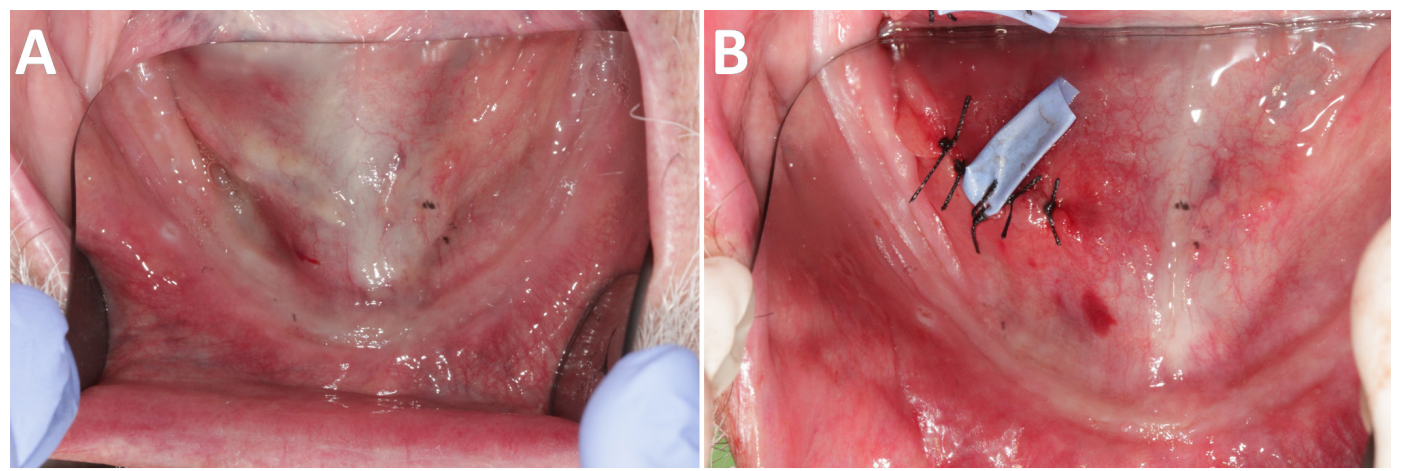

A) Preoperatív fotó: elődomborodó, sárgás színű, ép nyálkahártya a szájfenék premoláris-moláris régiójában; antibiotikum-terápia után akut gyulladásos jelek már nem láthatók. B) Primer sebzárás során sebészi gumidrént helyeztünk be 
ton-vezeték falait nem egyesítettük. A kivezetőcső metszésén kiáramló nyálretenciót és következményes ranulát megelőzendő, sebészi gumidrént helyeztünk a kivezetőcső, illetve szájüregi nyálkahártya közé és egyszerú csomós öltéssel a nyálkahártyasebszélhez rögzítettük. A varrat- és dréneltávolítást a hetedik posztoperatív napon végeztük. Egy hetet, illetve fél évet követően normális exkréciót figyeltünk meg a caruncula sublingualison keresztül. A fél éves posztoperatív idôszak tünet- és panaszmentesen alakult.

\section{Második eset}

A 61 éves nőbeteg fogorvosi beutalóval érkezett klinikánkra, a jobb submandibularis régió fájdalmas duzzanatával. Anamnézisünk szerint ischaemiás szívbetegség és essentialis hypertensio miatt az alábbi gyógyszeres terápiában részesült: trimetazidin, perindopril, indapamid, bisoprolol, amlodipin, izoszorbid-mononitrát és acetilszalicilsav.

Extraoralis vizsgálatunk során akut gyulladásos reakció egyértelmú jeleit láttuk a jobb submandibularis régióban. Nagyméretú, a submandibularis izomháromszöget teljesen kitöltő, meleg tapintatú terimét figyeltünk meg, amelyet erythemás, ép bőr borított. Anamnézisünkből kiderült, hogy páciensünk panaszai a jelenleg is érintett területen visszatérő jellegűek, a jelenleginél mérsékeltebb fájdalom és duzzanat évek óta időszakosan jelentkezett. Panaszok esetén fájdalomcsillapítót alkalmazott. Intraoralis, bimanuális vizsgálat során a szájfenék jobb oldalán, a középső-elülső harmadban körülbelül $3 \mathrm{~cm}$ hosszan kemény lágyszöveti duzzanatot tapintottunk. A terület érintésre rendkívül fájdalmasnak bizonyult, amely akadályozta a pontos bimanuális vizsgálatot, így jól körülhatárolt, nyálkőnek imponáló struktúrát nem tudtunk tapintani. A jobb submandibularis mirigyből, a Wharton-vezeték fiziológiás nyílásán keresztül genny volt préselhetô.

Panoráma- és CBCT-felvételeken körülbelül 27 $\mathrm{mm} \times 7$ mm-es méretû́, homogén röntgenárnyékot adó, jól körülhatárolható struktúra ábrázolódott a szájfenék középső-elülső harmadának megfelelően (3. C)-D) ábra). Az alapellátó fogorvos által rendelt, vizsgálatunk idején már megkezdett antibiotikum-terápia folytatását rendeltük el (clindamycin $4 \times 300 \mathrm{mg}$ naponta, 7 napig, per os). Simaizom-spasmolyticumot (drotaverin $3 \times 80$ mg naponta, per os), C-vitamint $(2 \times 500 \mathrm{mg}$ naponta), fokozott folyadékbevitelt ( $>3$ liter), illetve a nyálmirigy rendszeres masszázsát írtuk elő. A nyálkő eltávolítását a kezdeti kifejezett gyulladásos reakció miatt a gyógyszeres terápia végére halasztottuk.

Sialolithotomiára a gyógyszeres terápia negyedik napján került sor. Első esetünkhöz hasonlóan lokális érzéstelenítés mellett, intraoralis sebészi feltárásban távolítottuk el a nyálkövet, ezúttal egy darabban $(27 \mathrm{~mm} \times 7 \mathrm{~mm}$; $2,9 \mathrm{~g} ; 4$. ábra), majd sebészi gumidrént helyeztünk be

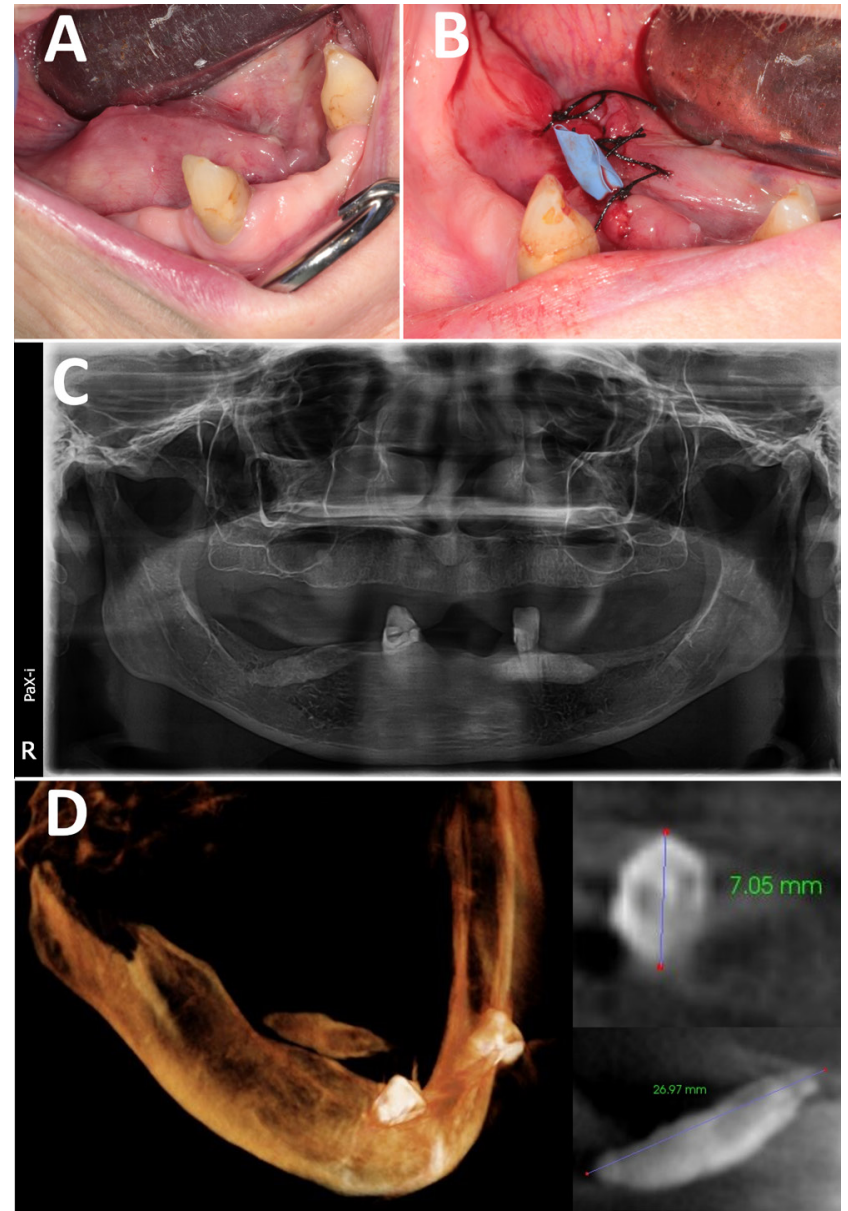

3. ábra

A) Kemény tapintatú és fájdalmas szájfenéki terime; akut gyulla dás jeleit mutató jobb oldali caruncula sublingualis. B) Posztoperatív fotó: primer sebzárás és varrattal rögzített sebészi gumidrén. C)-D) Panorámaröntgen és CBCT-felvételeken a szájfenék állományában, 3.3 fogtól distalisan ábrázolódó nagyméretü, radiodenz képlet, amely panorámafelvételen bilateralisan vetül

(3. B) ábra). Drén- és varrateltávolításra egy hét gyógyulást követően került sor, amely során a páciens teljes panaszmentességről számolt be.

\section{Megbeszélés}

Óriásnyálkővel ritkán találkozunk a klinikumban, előfordulásuk esetén döntô többségük $(94,4 \%)$ a submandibularis mirigyhez köthető [6]. A Wharton-vezetékben talált nyálkövek kimagasló aránya anatómiai és élettani tényezókre vezethető vissza: a fültőmirigyhez viszonyítva lúgosabb kémhatású, illetve magasabb kalcium- és mucintartalmú szekrétum; a kivezetőcső lefutásának kétszeres kanyarulata, valamint a nyál gravitációval ellentétes irányú exkréciója a legfontosabbak. Az alábbiakban eseteink felhasználásával röviden összefoglaljuk a ritka előfordulású, nagyméretû nyálkövek diagnosztikai nehézségeit és néhány eltávolítási módszer korlátait. 


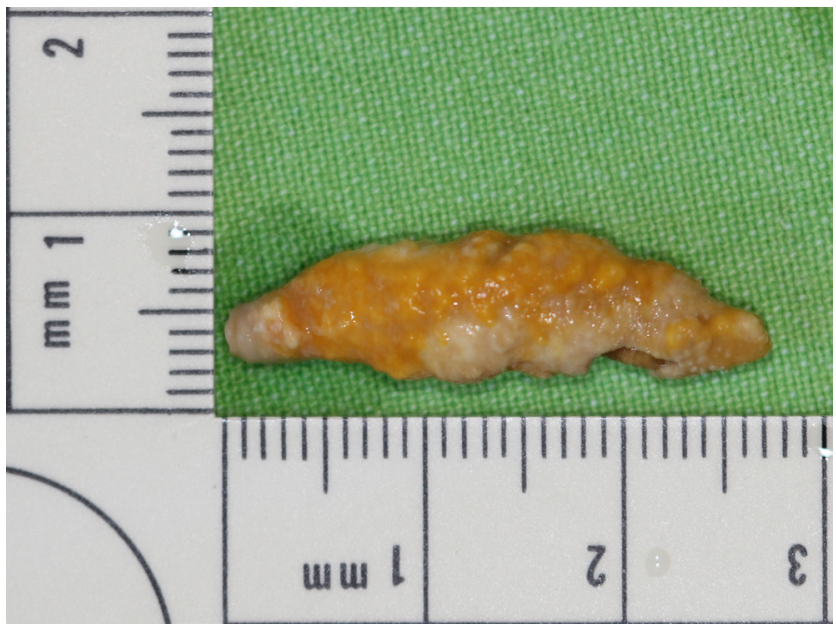

4. ábra
Eltávolított nyálkő: cilindrikus alakú, durva felszínű, sárgás szí nú és teljesen mineralizálódott; $27 \mathrm{~mm}$ hosszú és $2,7 \mathrm{~g}$
A sialolithiasis klinikai manifesztációja ahhoz az állapothoz köthető, amelyben a nyálkő jelentősen korlátozni képes az exkréciót. Az anamnézisből általában kiderül, hogy sialolithiasisra utaló tünetek már évekkel a tényleges diagnózis felállítása előtt megjelennek. Kivizsgálásra jellemzően az objektív tünetek - a gyulladás klasszikus öt tünete - ösztökélik a pácienst. A kimutatható, klinikailag is manifesztálódó nyálkövek kialakulásához szükséges időtartamot anamnézis alapján csak nagyfokú bizonytalansággal ítélhetjük meg. Klinikai bizonyíték a nyálkő formálódásának különböző stádiumairól, méretének növekedéséről és az ehhez szükséges időről pedig érthető okok miatt általában nem áll rendelkezésre. Első esetünk ritka radiológiai bizonyítékot szolgáltat arra, hogy egy 34 mm-es nyálkő kialakulásához szükséges idő hozzávetôlegesen 7 év.

A lágyrész-ultrahang, illetve radiológiai vizsgálat tekinthetők az elsődleges diagnosztikai eljárásoknak intézetünkben. Ultrahangvizsgálat nagy hatékonysággal 3 mm-nél nagyobb nyálkő kimutatására alkalmazható, ennek megfelelően óriásnyálkő egyértelmű echódús képletként echószegény hangárnyékkal ábrázolódik. Klinikai tapasztalatunk alapján az ultrahangvizsgálat sikeresen leírja az obstrukcióból eredő ductalis dilatatio jelenlétét, illetve a társuló sialadenitisnek megfelelő inhomogén, echószegény mirigyállományt [14], ugyanakkor a sialolith térbeli lokalizációját, méretét csak hozzávetőlegesen vagy egyáltalán nem is jellemzi. Az ultrahanglelet jellegéből adódik, hogy sebészi terápia tervezésére kevéssé alkalmas, így a diagnosztika nélkülözhetetlen eleme a panoráma-, illetve szükség szerint CBCT-röntgenfelvételek készítése, amelyek digitális formában egyúttal pontos mérést is lehetővé tesznek. Az óriásnyálkövek eddig leírt esetek alapján kivétel nélkül röntgenárnyékot adnak, mivel a növekedéshez szükséges idő elegendő a teljes kalcifikációhoz [8]. A sialolithiasisra jellemző akut tünetek karakterisztikusak, a diagnózis felállítása megfelelő képalkotó vizsgálatokat követően általában nem jelent nehézséget, ugyanakkor a hosszú, gyakran tünetszegény latenciaidő alatt a sialolithiasis lehetőségének felismerése kihívást jelenthet. Első esetünknél - vizsgálatunkat megelőzően hét évvel - elmulasztották a nyálkőképződés felismerését, annak ellenére, hogy a panoráma-röntgenfelvételen, a bal sublingualis területnek megfelelően egy jól körülhatárolható radioopacitás volt látható (1. ábra). A röntgenfelvétel készítésekor tünet- és panaszmentes de hosszabb távon tünetszegény és panaszokat is produkáló - állapot nem vetette fel a további klinikai vizsgálatok szükségességét. A diagnózis elmulasztása nemcsak további méretbeli növekedést vonhat maga után, hanem hozzájárul a mirigyállomány atrófiájához és a nyálmirigyfunkció csökkenéséhez, illetve nyálmirigy-diszfunkcióhoz. Egyéb maxillofacialis meszesedések, mint tonsillakő, elmeszesedett nyirokcsomó, phlebolith, atheroscleroticus plakk is mutathatnak nyálkőhöz hasonló radiológiai jeleket, de a röntgenárnyékot adó képlet(ek) anatómiai elhelyezkedése, eloszlása, száma, alakja és méretei alapján eredetükre egyértelmú klinikai jelek nélkül is fény derül általában panoráma-röntgenfelvétel alapján. $\mathrm{Az}$ oropharyngealis meszesedések legtöbbször tünetmentesek. Panoráma-röntgenfelvételen tonsillakő egyszeres vagy többszörös radioopacitásként, a mandibula ramus középső sávjában ábrázolódik, ennek megfelelően a Stenon-vezetékben vagy a fültőmirigy állományában elhelyezkedő nyálkőhöz hasonló röntgenárnyékot adhat $[15,16]$. Elmeszesedett nyirokcsomók elhelyezkedése a submandibularis régióban és az angulus mandibulae környezetében gyakori, amely közel esik a submandibularis mirigy anatómiai pozíciójához. A mirigyállományban formálódó nyálkövek röntgenárnyéka tehát elmeszesedett nyirokcsomónak is imponálhat [12]. A ligamentum stylohyoideum általában a ramus mandibulae posteroinferior határát metszi, míg az atheroscleroticus plakkok az angulus mandibulaetól caudalisan, a cervicalis csigolyák közelébe, a C3-C4 csigolyák vonalába vetülnek, tehát mindkét laesio viszonylag távol képeződik le a sublingualis területtôl, illetve a submandibularis háromszögtől, ahol a nyálmirigyállomány, illetve a Wharton-vezeték található [17]. A phlebolitok érhálózatban található kalcifikált thrombusok, panaszt nem okoznak, így mellékleletként kerülnek felismerésre. Röntgenfelvételen kerek, multiplex megjelenésüek. A nagyméretü phlebolitok lamellált struktúrát mutathatnak radiolucens maggal, amely nagyobb nyálkő röntgenképét utánozhatja. A jelenség megfigyelhető az első esetünkről készült panorámafelvételen (1. A) ábra). A pontos diagnózist nehezítő, megtévesztő lokalizáció esetén CBCT-felvétel vagy sialographia segítségével a két különböző természetű laesio egymástól egyértelmúen differenciálható [18]. Nagyméretü nyálkövek CBCT-képalkotás felhasználásával egyértelmúen elkülöníthetők az állkapocs-hiperdenzitással járó laesióitól, az oropharyngealis lágyrész-kalcifikációktól, panorámafelvételen ábrázolódó mütermékektől, illetve árnyékoktól. Klinikai tapasztalatunk alapján a Wharton-vezetékben elhelyezkedő nagyméretű nyálkő a 
szájfenék bimanuális vizsgálata során jól körülhatárolható, konzisztenciáját tekintve kemény, kőnek imponáló, ugyanakkor a meglévő gyulladásos reakció jelentősen csökkentheti a manuális vizsgálat hatékonyságát. A nagyméretű nyálkövek által okozott teljes obstrukció, sialooralis fistula kialakulásához is vezethet, és a nyálkő felszíne akár láthatóvá is válhat a fistulanyílásban, amely már a klinikai vizsgálat során egyértelmúvé teszi a diagnózist [13]. Említésre méltó, hogy a középvonal közelében található kalcifikációk gyakran bilaterális képletként jelennek meg a panorámafelvételen (3. C) ábra) [19], de a röntgenárnyékot adó struktúrát ténylegesen tartalmazó oldalon a képlet élesebb határokkal rajzolódik ki.

$\mathrm{Az}$ intraoralis sebészi sialolithotomia régóta alkalmazott terápiás megoldás, amely minden kivezetőcsőben elhelyezkedő nyálkő esetén alkalmazható, beleértve a Wharton-vezeték proximális hajlatát is [19]. A kis (<3 mm) és a közepes (<7 mm) méretű nyálkövek eltávolítására egyre szélesebb körben alkalmazott eszköz a szialoendoszkóp. Ugyanakkor nagyméretű (átlagosan $8,2 \mathrm{~mm}$ ) nyálkövek eltávolítása során még az intraoralis segédmetszés mellett alkalmazott szialoendoszkópos technika is kevés sikeres eltávolítást hozott (33\%) [9]. Amennyiben óriásnyálkő jelenléte igazolódik a Wharton-vezeték szájfenéki szakaszán, transoralis sebészi eltávolítás javasolható, amelynek két technikája közül választhatunk: primer zárás vagy a sialodocho-plasztika. Intézetünkben a primer zárást részesítjük előnyben a Wharton-vezeték falainak egyesítése nélkül.

A nyálmirigy kivezetőcsövének hosszú távú obstrukciója sialadenitishez és következményes fibrosishoz, illetve mirigyatrófiához vezethet [1]. Mindkét esetünknél az egyéves kontrollvizsgálatunk során tünet- és panaszmentes állapotot figyeltünk meg. A submandibularis mirigy masszázsával víztiszta, fiziológiás mennyiségú nyálat préseltünk, nyálmirigy-diszfunkció jeleit (xerostomia stb.) nem figyeltünk meg. A sialolithotomiát követően megfigyelt kiváló mirigyfunkcióból arra következtethetünk, hogy hét-nyolc éves latens nyálkőképződést, illetve krónikus obstrukciót követően is reális esély van a mirigyfunkció teljes regenerációjára. Az általunk követett protokoll ideális megoldásnak tünik a Wharton-vezetékben elhelyezkedő óriásnyálkövek sebészi kezelésére.

Anyagi támogatás: A közlemény megírása, illetve a kapcsolódó kutatómunka anyagi támogatásban nem részesült.

Szerzői munkamegosztás: A munka a szerzők közös érdeme. A cikk végleges változatát valamennyi szerző elolvasta és jóváhagyta.

Érdekeltségek: A szerzőknek nincsenek érdekeltségeik.

\section{Irodalom}

[1] Harrison, J. D.: Causes, natural history, and incidence of salivary stones obstructions. Otolaryngol. Clin. North Am., 2009, 42(6), 927-947.

[2] Huoh, K. C., Eisele, D. W.: Etiologic factors in sialolithiasis. Otolaryngol. Head Neck Surg., 2011, 145(6), 935-939.

[3] McGurk, M., Escudier, M. P., Brown, J. E.: Modern management of salivary calculi. Br. J. Surg., 2005, 92(1), 107-112.

[4] Lustmann, J., Regev, E., Melamed,. .: Sialolithiasis. A survey on 245 patients and a review of the literature. Int. J. Oral Maxillofac. Surg., 1990, 19(3), 135-138.

[5] Grases, F., Santiago, C., Simonet, B. M., et al.: Sialolithiasis: mechanism of calculi formation and etiologic factors. Clin. Chim. Acta, 2003, 334(1-2), 131-136.

[6] Ledesma-Montes, C., Garcés-Ortiz, M., Salcido-García, J. F., et al.: Giant sialolith: case report and review of the literature. J. Oral Maxillofac. Surg., 2007, 65(1), 128-130.

[7] Szalma, J., Böddi, K., Lempel, E., et al.: Proteomic and scanning electron microscopic analysis of submandibular sialoliths. Clin. Oral Investig., 2013, 17(7), 1709-1717.

[8] Bodner, L.: Giant salivary gland calculi: diagnostic imaging and surgical management. Oral Surg. Oral Med. Oral Pathol. Oral Radiol. Endod., 2002, 94(3), 320-323.

[9] Atienza, G., López-Cedrún, J. L.: Management of obstructive salivary disorders by sialendoscopy: a systematic review. Br. J. Oral Maxillofac. Surg., 2015, 53(6), 507-519.

[10] Koch, M., Mantsopoulos, K., Schapher, M., et al.: Intraductal pneumatic lithotripsy for salivary stones with the StoneBreaker: Preliminary experience. Laryngoscope, 2016, 126(7), 1545-1550.

[11] Omezli, M. M., Ayranci, F., Sadik, E., et al.: Case report of giant sialolith (megalith) of the Wharton's duct. Niger. J. Clin. Pract., 2016, 19(3), 414-417.

[12] Németh, B., Ujpál, M., Németh, Zs., et al.: Unusual form of sialolithiasis: case report with 3-dimensional imaging (Letter to the Editor). Br. J. Oral Maxillofac. Surg., 2016, 54(1), el7.

[13] Szalma, J., Orsi, E., Nyárády, Z., et al.: Submandibular sialolith: case report and review of the literature. [Nagyméretü submandibularis nyálkő és sialo-oralis fistula. Esetismertetés és irodalmi áttekintés.] Fogorv. Sz., 2008, 101(6), 219-223. [Hungarian]

[14] Szalma, J., Olasz, L., Tóth, M., et al.: Diagnostic value of radiographic and ultrasonic examinations in patients with sialoadenitis and sialolithiasis. [Röntgen- és ultrahangvizsgálatok értékelése sialoadenitises és sialolithiasisos betegcsoportokban.] Fogorv. Sz., 2007, 100(2), 53-58. [Hungarian]

[15] Mody, R. N., Srivastava, S.: Bilateral multiple tonsilloliths. Oral Radiol., 2009, 25(1), 67-70.

[16] Shimizu, M., Yoshiura, K., Nakayama, E., et al.: Multiple sialolithiasis in the parotid gland with Sjögren's syndrome and its sonographic findings - report of 3 cases. Oral Surg. Oral Med. Oral Pathol. Oral Radiol. Endod., 2005, 99(1), 85-92.

[17] Tarm Ertas, E., Mavili, E., Sisman, ., et al.: Incidental finding of carotid artery stenosis detected by calcifications on panoramic radiographs: report of three cases. Oral Radiol., 2010, 26(2), 116-121.

[18] Mandel, L., Perrino, M. A.: Phleboliths and the vascular maxillofacial lesion. J. Oral Maxillofac. Surg., 2010, 68(8), 19731976.

[19] Baurmash, H. D.: Submandibular salivary stones: current management modalities. J. Oral Maxillofac. Surg., 2004, 62(3), 369378 .

(Szalma József dr.,

Pécs, Dischka Győző u. 5., 7621 e-mail: szalma.jozsef@pte.hu) 